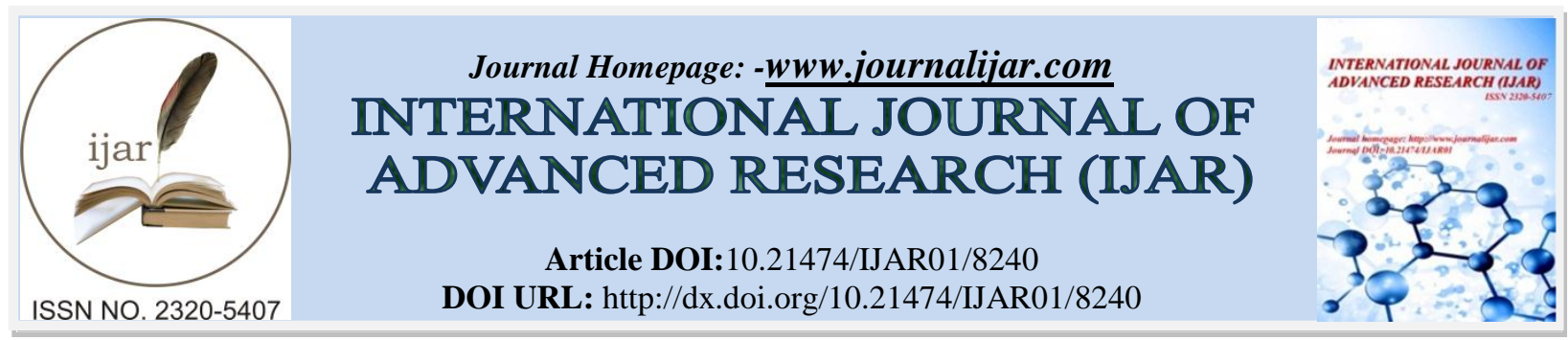

RESEARCH ARTICLE

\title{
VALUE ENGINEERING ANALYSIS OF BEAM STRUCTURE ON GOLD FACTORY DEVELOPMENT PROJECT.
}

Siti Choiriyah and Kahfi Rizqi Wibowo.

Department of Civil Engineering, Adhi Tama Institute of Technology Surabaya, Indonesia.

\section{Manuscript Info}

\section{Manuscript History}

Received: 18 October 2018

Final Accepted: 20 November 2018

Published: December 2018

Key words:-

Value Engineering, Beam Structure, Cost Saving.

\begin{abstract}
High demand in construction building materials certainly calls for material energy savings in order to secure project efficiency. The research was identity ineffectiv cost in structural works in a gold plant construction project. To prevent such inefficiency, value engineering method was adopted to secure cost efficiency. In tehe adoption of the value engineering analysis applied to beam structural works in a gold plant construction project, the researcher observed i item of job leading to loss cost the most, i,e. :beem structural works. The value engineering analysis application adopted was zero one method to generate a recomendation for beam strucutural works, i,e. :alternative 1 , saving as much as IDR $157,675,945$ or $8.44 \%$ of the total costs of beam structural works with a saving percentage by $1.54 \%$ of the total project costs.
\end{abstract}

Copy Right, IJAR, 2017,. All rights reserved.

\section{Introduction:-}

Developments in the field of construction in Indonesia are things that need to be considered in its implementation, many obstacles are often found which might be detrimental to the service providers involved in a construction development. To prevent these losses, it is necessary to have an efficient budget plan to minimize unnecessary costs. One way that service providers can do to reduce unnecessary costs is by implementing value engineering analysis (VE).

Value Engineering is an organized and creative approach that aims to identify unnecessary costs (Miles, 1971). Unnecessary costs are costs that do not provide quality, usability, something that revives a good appearance or the nature desired by consumers.

Beam structure work is a typical work item, has a large cost. Need a creative idea to optimize the cost of building the project by replacing existing planning. The replacement of beam structure work with other alternatives will certainly have an effect in terms of cost and time of implementation, so that a method is needed in the form of engineering which aims to reduce unnecessary costs. The application of value engineering analysis techniques using the zero-one method is expected to reduce the risk of swelling the costs incurred.

Research on value engineering analysis of beam structure work was chosen because in this technique high value work will be directly proportional to the savings obtained. Thus, the value engineering applied to high-value jobs will have the potential to save costs on the PT. Damai Karunia Sejahtera Kenjeran.

\section{Corresponding Author:-Siti Choiriyah.}

Address:-Department of Civil Engineering, Adhi Tama Institute of Technology Surabaya, Indonesia. 


\section{Methods:-}

To solve the problems that occur, the author uses quantitative descriptive research by making descriptions of accurate images then calculated systematically and analyzed to bring out the best alternatives by conducting a case study on the Damai Karunia Sejahtera gold plant construction project.The research process is divided into 5 stages including the information stage, the creative stage, the analysis phase, the development stage and the recommendation stage.

\section{Results and Discussion:-}

\section{Information stage;-}

In the information stage, several ways are used to identify the work that value engineering will do, including breakdown of the model and analysis of functions. Cost models are work charts that are grouped according to the elements of each work.

From the recapitulation of the cost of the budget plan (RAB) breakdown is carried out on the structure work. For more details, see Table 1 .

Table 1:-Breakdown Cost Model Proyek Pabrik Emas

\begin{tabular}{|l|lr|}
\hline WORK BASIC FLOOR S / D FLOOR 3 & Cost & \\
\hline 1. Beam & $\mathrm{Rp}$ & 1.868 .786 .728 \\
\hline 2. Coloumn & $\mathrm{Rp}$ & 916.210 .083 \\
\hline 3. Stairs & $\mathrm{Rp}$ & 145.315 .660 \\
\hline 4. Pelat Lantai & $\mathrm{Rp}$ & 1.814 .899 .839 \\
\hline 5. Sloof & $\mathrm{Rp}$ & 427.702 .120 \\
\hline
\end{tabular}

From the breakdown table, the above model can be seen that work items on the 1st to 3rd floor have the highest cost with a percentage of $67.69 \%$, so that on the work item, value engineering analysis will be carried out to obtain potential savings.

The second stage in the information phase is the analysis of functions used to explain the basic functions and secondary functions of work items and to get a comparison between value of cost (cost) with value of benefit (worth). Analysis of the function of beam work can be seen in Table 2. Because both the cost / worth ratio shows a value of more than 1 , then the potential beam work for value engineering is done.

The next step to get the priority feasibility of work items to do a value engineering, needs to be analyzed with a pareto graph which can be seen in figure 1

Table 2:-Analysis of Beam Function Functions

\begin{tabular}{|c|c|c|c|c|c|c|}
\hline \multirow{2}{*}{$\begin{array}{l}\mathrm{N} \\
\mathrm{o}\end{array}$} & \multirow[t]{2}{*}{ Component } & \multicolumn{3}{|l|}{ Fungsi } & \multirow[t]{2}{*}{ Cost (Rp) } & \multirow[t]{2}{*}{ Worth (Rp) } \\
\hline & & Verb & $\begin{array}{l}\text { Nou } \\
\mathrm{n}\end{array}$ & Kind & & \\
\hline 1 & Rebar & conduct & load & $P$ & 1.280 .321 .093 & 1.280 .321 .093 \\
\hline 2 & Beam & conduct & load & $\mathrm{P}$ & 288.720 .626 & 288.720 .626 \\
\hline 3 & $\begin{array}{l}\text { Formwork } \\
\text { Scaffolding }\end{array}$ & mold & $\begin{array}{l}\text { bea } \\
\mathrm{m}\end{array}$ & S & 299.745 .008 & - \\
\hline & & & & Jumlah & 1.868 .786 .728 & 1.569 .041 .719 \\
\hline & Jenis : & & & Ratio & 1,19 & \\
\hline & $\begin{array}{l}\mathrm{P}=\text { Basic function }(\mathrm{Pr} \\
\mathrm{S}=\text { Supporting Functi }\end{array}$ & er) & & $\mathrm{C} / \mathrm{W}$ & & \\
\hline
\end{tabular}




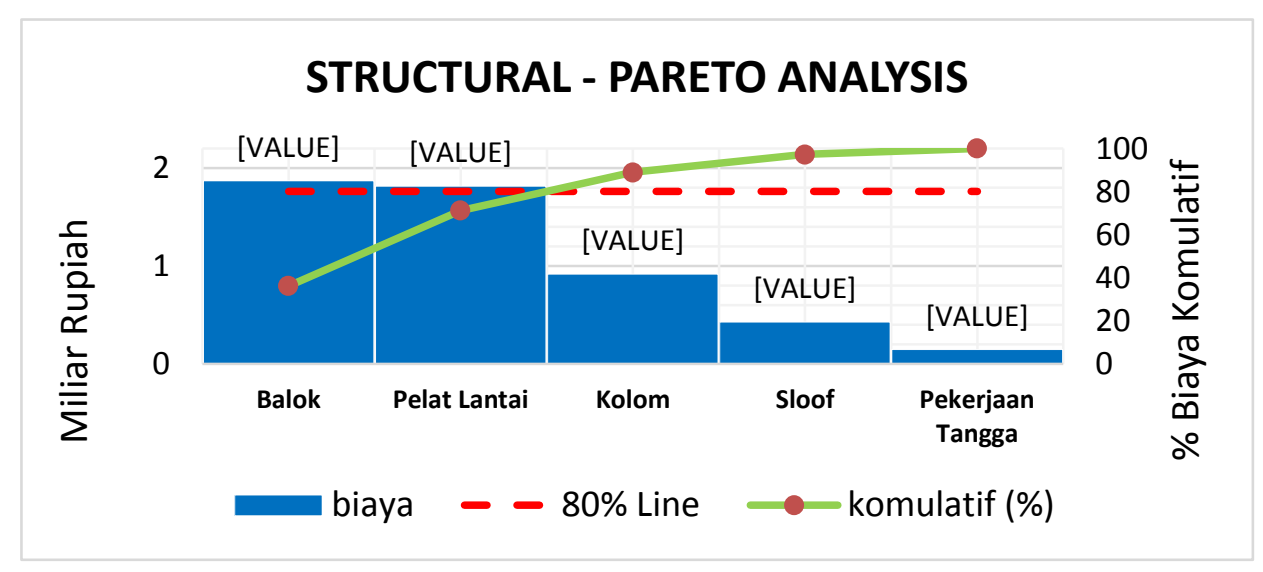

Figure 1:-Pareto Analysis Chart

\section{Creative Stage:-}

At this stage there are several alternative alternatives for beam structure work from brainstorming techniques, so that with the emergence of several alternatives this idea is expected to be cost savings. An alternative substitute for beam structure work can be seen in table 3 .

Tabel 3:-Alternatif pelaksanaan struktur balok

\begin{tabular}{|l|l|}
\hline Existing Beam & Implementation Using Scafolding Frame \\
\hline Alternative Beams 1 & Implementation Using Scafolding PCH \\
\hline Alternative Beams 2 & Implementation Using Scafolding Pipes \\
\hline Alternative Beams 3 & Implementation Using Bamboo Scafolding \\
\hline Existing Beams & Implementation Using Scafolding Frame \\
\hline Alternative Beams 1 & Implementation Using Scafolding PCH \\
\hline Alternative Beams 2 & Implementation Using Scafolding Pipes \\
\hline Alternative Beams 3 & Implementation Using Bamboo Scafolding \\
\hline
\end{tabular}

\section{Analysis Phase:-}

Alternatives that have been raised are then analyzed by assessing the quality and calculating the costs of each alternative in order to determine the value of the best alternative. Profit and Loss Analysis can be seen in table 4.

Tabel 4:-Profit and Loss Analysis

\begin{tabular}{|c|c|c|c|}
\hline No & Alternative & Profit & Loss \\
\hline 1 & $\begin{array}{l}\text { Implementation } \\
\text { Scafolding PCH }\end{array}$ & $\begin{array}{l}\text { - Scaffolding work is } \\
\text { relatively easy compared to } \\
\text { existing }\end{array}$ & - Scafolding PCH suppliers are still rare \\
\hline 2 & $\begin{array}{l}\text { Implementation } \\
\text { Scafolding Pipes }\end{array}$ & $\begin{array}{l}\text { - Scafolding rental prices } \\
\text { are more economical }\end{array}$ & $\begin{array}{l}\text { - Difficult to adjust to the conditions in the } \\
\text { field because of the size of the pipe that is } \\
\text { fixed }\end{array}$ \\
\hline 3 & $\begin{array}{l}\text { Implementation of Using } \\
\text { Bamboo Scaffolding }\end{array}$ & $\begin{array}{l}\text { - Bamboo material is easily } \\
\text { available } \\
\text { - The price of bamboo } \\
\text { materials is cheaper } \\
\text { - Scaffolding can reach } 5 \mathrm{~m} \\
\text { high }\end{array}$ & $\begin{array}{l}\text { - Easy to weather } \\
\text { - Implementation in the field is relatively } \\
\text { long } \\
\text { - Can not be used more than } 2 x \\
\text { - Only can be used within } \pm 4 \text { months }\end{array}$ \\
\hline
\end{tabular}

Alternative Selection Analysis:-

Alternative selection in the ranking uses the Zero-One method so that poor alternatives will be eliminated automatically. For the determination of Zero-One looking for the weight of researchers using primary data in the form of interviews with site managers can be seen in table 5. For the zero-one method looking for an index can be seen in table 6-9. From the results of searching for weights and searching for indexes, an evaluation matrix can be made that functions as a ranking. The evaluation matrix can be seen in table 10 . 
Tabel 5:-Zero-One looking for weight method

\begin{tabular}{|l|l|l|l|l|l|l|l|l|l|}
\hline No & Criteria & $\begin{array}{l}\text { Criteria } \\
\text { Number }\end{array}$ & 1 & 2 & 3 & 4 & Total & Ranking & Weight \\
\hline 1 & $\begin{array}{l}\text { Ease of } \\
\text { Implementation }\end{array}$ & 1 & $\mathrm{X}$ & 0 & 0 & 0 & 0 & 1 & 10,00 \\
\hline 2 & Financing & 2 & 1 & $\mathrm{X}$ & 1 & 1 & 3 & 4 & 40,00 \\
\hline 3 & Time & 3 & 1 & 0 & $\mathrm{X}$ & 1 & 2 & 3 & 30,00 \\
\hline 4 & Quality & 4 & 0 & 0 & 1 & $\mathrm{X}$ & 1 & 2 & 20,00 \\
\hline
\end{tabular}

Tabel 6:-The Zero-One Method Looks for the Ease of Implementation Criteria Index

\begin{tabular}{|l|l|l|l|l|l|l|}
\hline Function & A & B & C & D & Total & Index \\
\hline A & X & X & 1 & 1 & 2 & 0,40 \\
\hline B & X & X & 1 & 1 & 2 & 0,40 \\
\hline C & 0 & 0 & X & 1 & 1 & 0,20 \\
\hline D & 0 & 0 & 0 & X & 0 & 0,00 \\
\hline
\end{tabular}

Tabel 7:-The Zero-One Method Looking for a Financing Criteria

\begin{tabular}{|l|l|l|l|l|l|l|}
\hline Function & A & B & C & D & Total & Index \\
\hline A & X & 0 & 0 & 1 & 1 & 0,17 \\
\hline B & 1 & X & 1 & 1 & 3 & 0,50 \\
\hline C & 1 & 0 & X & 1 & 2 & 0,33 \\
\hline D & 0 & 0 & 0 & X & 0 & 0,00 \\
\hline
\end{tabular}

Tabel 8:- The Zero-One Method Searches for the Time Criteria Index

\begin{tabular}{|l|l|l|l|l|l|l|}
\hline Function & A & B & C & D & Total & Index \\
\hline A & X & 0 & 1 & 1 & 2 & 0,33 \\
\hline B & 1 & X & 1 & 1 & 3 & 0,50 \\
\hline C & 0 & 0 & X & 1 & 1 & 0,17 \\
\hline D & 0 & 0 & 0 & X & 0 & 0,00 \\
\hline
\end{tabular}

Tabel 9:- The Zero-One Method Looking for a Quality Criteria Index

\begin{tabular}{|l|l|l|l|l|l|l|}
\hline Function & A & B & C & D & Total & Index \\
\hline A & X & X & X & 1 & 1 & 0,33 \\
\hline B & X & X & X & 1 & 1 & 0,33 \\
\hline C & X & X & X & 1 & 1 & 0,33 \\
\hline D & 0 & 0 & 0 & X & 0 & 0,00 \\
\hline
\end{tabular}

Tabel 10:-Matriks Evaluasi

\begin{tabular}{|c|c|c|c|c|c|c|c|}
\hline \multirow[t]{3}{*}{ No } & \multirow{2}{*}{\multicolumn{2}{|c|}{ Fungtion }} & \multicolumn{4}{|c|}{ Criteria } & \multirow[t]{3}{*}{ Total } \\
\hline & & & 1 & 2 & 3 & 4 & \\
\hline & \multicolumn{2}{|r|}{ Weight } & 10,00 & 40,00 & 30,00 & 20,00 & \\
\hline \multirow[t]{2}{*}{1} & \multirow[t]{2}{*}{$\mathrm{A}$} & $\mathrm{I}=$ & 0,33 & 0,00 & 0,20 & 0,00 & \multirow[t]{2}{*}{9,33} \\
\hline & & $\mathrm{B} \times \mathrm{I}=$ & 3,33 & 0,00 & 6,00 & 0,00 & \\
\hline \multirow[t]{2}{*}{2} & \multirow[t]{2}{*}{ B } & $I=$ & 0,33 & 0,33 & 0,60 & 0,00 & \multirow[t]{2}{*}{34,67} \\
\hline & & $\mathrm{B} \times \mathrm{I}=$ & 3,33 & 13,33 & 18,00 & 0,00 & \\
\hline \multirow[t]{2}{*}{3} & \multirow[t]{2}{*}{$\mathrm{C}$} & $\mathrm{I}=$ & 0,33 & 0,50 & 0,20 & 0,00 & \multirow[t]{2}{*}{29,33} \\
\hline & & $\mathrm{B} \times \mathrm{I}=$ & 3,33 & 20,00 & 6,00 & 0,00 & \\
\hline \multirow[t]{2}{*}{4} & \multirow[t]{2}{*}{$\mathrm{D}$} & $I=$ & 0,00 & 0,17 & 0,00 & 0,00 & \multirow[t]{2}{*}{6,67} \\
\hline & & $\mathrm{B} \times \mathrm{I}=$ & 0,00 & 6,67 & 0,00 & 0,00 & \\
\hline
\end{tabular}




\section{Development Phase:-}

Because the work of the Beams has been planned to hold the load strong, it does not require operational and maintenance costs. For this reason, calculation is not carried out at this stage.

\section{Recommendation Phase:-}

The final stage in carrying out value engineering is to provide recommendations on the results of studies that have been conducted.

\section{Preliminary Design:-}

Beam Structure Work with Scafolding Frame

\section{Recommended:-}

Alternative Beam Structure Work 1 (Beam Work Implementation Using Scafolding PCH)

1. Requires a work fee of Rp. 1,711,1010,783, so that a cost savings of Rp. 157,675,945.

2. Uninstall Scafolding PCH faster because the support uses vertical support (which is more flexible than the scafolding frame)

\section{Conclusions:-}

From the value engineering analysis (VE) conducted on the Kenjeran gold plant construction project conclusions can be taken as follows:

The application of value engineering analysis on the beam produces 3 alternatives, namely the implementation of beam work using PCH scafolding, scafolding pipes and bamboo scaffolding. then obtained alternative work 1 (scafolding PCH) as the best alternative, because this alternative has a high total value in the evaluation matrix table of 34.67 .

From the application of the value engineering analysis, the recommendations are in the form of replacing the existing beam structure work with alternative 1 which has a work cost of Rp. 1,711,110,783 so as to generate savings as much as Rp. $157,675,945$ or as large as $8.44 \%$ of the total cost of the beam structure work and has a percentage of savings of $1.54 \%$ of the total project cost.

\section{Reference:-}

1. Barrie, Donald S. \& Boyd C. Paulson Jr. 1984. Manajemen Konstruksi Profesional Edisi kedua. Alih Bahasa

2. Sudinarto. 1990. Edisi Kedua. Jakarta : Erlangga

3. Cahaya, Haposan I. T. dkk. 2017. Penerapan Rekayasa Nilai (Value Engineering) pada Pembangunan Gedung

4. Kantor Pt. Asuransi Jasa Indonesia di Kota Pematang Siantar. Vol 6, No 1 (2017)

5. Cahyadi, Hendra. 2017. Bahan Kuliah Rekayasa Nilai UM Palangkaraya.

6. (umpalangkaraya.ac.id/dosen/hendracahyadi/wp-content/uploads/2017/09/Bahan) Accesed date 24/04/2018

7. Hidayat Achmad Nurul, dan Ardianto Denny. 2011. Rekayasa Nilai Pembangunan Gedung Rusunawa Amabarawa.

8. Skripsi. Semarang : Fakultas Teknik Universitas diponegoro Semarang.

9. Kaizen, Star Consulting. Analisis Pareto Langkah Demi Langkah.

10. (https://smkberkaizen.wordpress.com/2011/09/18/analisis-pareto-langkah-demi-langkah/) Accesed date $11 / 08 / 2018$

11. Nurcahya, Hendra. (2016). Efisiensi Biaya Penggunaan Bahan Penutup Kolom dan Listplank dengan Metode Value

12. Engineering. Skripsi Tidak Diterbitkan. Surabaya : Fakultas Teknik Sipil dan Perencanaan Institut Teknologi

13. Adhitama Surabaya.

14. Project, Teknik Area. Tabel Berat Besi Polos / Ulir. (http://komunitas-anak-teknik.blogspot.com/2010/10/tabel

15. berat-besi-polos.html?m=1) Accesed date 05/09/2018

16. Rahma, Diyar dkk. (2017). Analisis Value Engineering dengan Metode Zero-One pada Proyek Pembangunan

17. Gedung Laboratorium Komputer Kampus 3 Universitas Ahmad Dahlan Yogyakarta. Skripsi. Semarang : Fakultas

18. Teknik Universitas diponegoro Semarang.

19. Rani, A Hafnidar. (2015). Penerapan Value Engineering Pada Pembangunan Jembatan Penggandaan Menuju 
20. Infrastruktur Yang Efektif, Efisien Dan Berkelanjutan. (https://mpinfrastruktur.blogspot.com/2015/10/valueengineering.html) Accesed date 16/10/2018

21. Sastraatmaja, Soedradjat. 1984. Analisa Cara Modern Anggaran Biaya Pelaksanaan. Bandung : Nova

22. Seng Hansen, S.T., M.Sc. 2017. Manajemen Kontrak Konstruksi. Edisi Kedua. Jakarta : Gramedia Pustaka Utama.

23. Trijeti. 2016. Studi Perbandingan Bekisting Konvensional dengan PCH (Perth Construction Hair)

24. Utomo, Adi Setyo. 2016. Analisis Rekayasa Nilai yang Diterapkan pada Pekerjaan Dinding dan Rangka Atap di

25. SDN Sumurwelut III Surabaya. Skripsi tidak diterbitkan. Surabaya : Fakultas Teknik Sipil dan Perencanaan Institut.

26. Teknologi Adhitama Surabaya. 